\title{
MIR138-2 wt Allele
}

National Cancer Institute

\section{Source}

National Cancer Institute. MIR138-2 wt Allele. NCI Thesaurus. Code C82093.

The human MIR138-2 wild-type allele is located in the vicinity of $16 q 13$ and is 83 bases in length. This allele, which encodes MIR138-2 pre-miRNA, plays a role in the regulation of gene expression. Alteration in the expression of this gene is associated with development of anaplastic thyroid carcinoma. 